\title{
Embracing the digitalization of research education? How social science research education was influenced by the COVID-19 pandemic
}

\author{
Dimitri Prandner, Katrin Hasengruber \\ Department of Sociology - Empirical Research Unit, Johannes Kepler University of Linz, \\ Austria.
}

\begin{abstract}
The COVID-19 pandemic led to a strong digitalization push at university level teaching. The latter had to be converted to distance modes quickly. This paper discusses the consequences of these developments for the field of social science research education, a discipline where the personal interaction between lecturers and students traditionally plays a major role in the transfer of knowledge and competences. Accordingly, we ask whether lecturers accepted distance learning as part of their work and if they will implement the associated digital teaching modalities into their regular teaching repertoire in the future. Furthermore, indicators shaping the acceptance of future distance teaching are explored.

The article is based on a continuous online survey of lecturers $(n=169)$ who teach social science methods and methodology at Austrian public universities. The results of this study show that more than $40 \%$ of the sample with or after the experience of distance teaching will retain some aspects of it in their teaching due to the CODIV-19 pandemic. In particular, the evaluation of the preparation effort, the interaction with students and the attitude toward new didactic methods play a central role in the acceptance of distance teaching.
\end{abstract}

Keywords: Digitization; social science; research methods; distance teaching. 


\section{Introduction - How Research and Methods Education Changed Overnight}

Academia has been entrenched in controversial discussions about the potential consequences of relying on distance learning and teaching in tertiary education for a long time (Marshall, 2018). However, those discussions have been halted during the COVID-19 crisis of 2020 and 2021 because the pandemic made distance teaching and learning common at most universities. Thus, it can be argued that now, perhaps more than ever before, the long-term future of higher education has become linked to the digital transformation, where all hypothetical ifs and buts have been replaced by the reality of distance education, based on online lectures and assessments (Ali, 2020; Tømte et al., 2019).

While this abrupt change has been an unusual experience in many ways (Watermeyer et al., 2020), it also had different effects on the equally different scientific domains and disciplines. The following paper engages with the consequences of those developments in the field of social science research education. Consequently, it will be discussed whether lecturers are (1) accepting distance learning as part of their job and (2) if they are going to implement the related digital teaching modalities into their regular future teaching repertories. Following up on the results of this descriptive analysis, characteristics influencing educators' opinions will be identified.

The domain of research methods education in social sciences is of great interest because of two principal reasons: Firstly, bestowing students with the abilities to conduct research and providing them with the skills necessary to distinguish between trustworthy empirical claims and invalid assertions is a key takeaway from social science studies and often one of the more practical and employment-relevant aspects of university graduates in the related disciplines (Nardi, 2018; Prandner \& Tabakovic, 2019). Therefore, it is central for students to develop a strong grasp of the underlying concepts. Secondly, courses dealing with such issues are commonly among the most challenging in university teaching for both students and lecturers (Earley, 2014). Because of this, such classes rely heavily on in-person teaching, personal interaction during tutorials and close proximity when it comes to data analysis sessions. This expands to many forms of data collection (e.g. interviews, face to face surveys) which are typically part of social science research training. However, because of the restrictions put in place during the COVID-19 pandemic teaching in person or even engaging with others for data collection purposes became much harder or even impossible.

The empirical foundation for this discussion is based on a case study from Austria which has (currently) two waves of quantitative data to draw upon. The population of the study are social science research lecturers in Austria who teach at public universities. Section 2 will introduce the current state of research and theoretical arguments, while section 3 will give an overview of the empirical material. Subsequently, the results will be presented (4) and a discussion closes the paper (5). 


\section{Social Science Research Education, What Is Expected from It and How Does This Relate to the Digitalization of Education?}

Despite the fact that online education had been on a steady increase even before the COVID19 pandemic struck, digitalization of both university level education and distance teaching are highly contested topics in debates about higher education (Ali, 2020; Zhang et al., 2020). There has been an institutional resistance in academia to adapt to online teaching, especially when it comes to more application-based content that demands a high level of student and lecturer interaction, citing quality concerns as primary reasons (Ivancheva et al., 2020). In this regard, it has to be stated that the introduction of technology and systemic change is always a challenge. This is also true for online teaching in higher education, with several factors influencing satisfaction and acceptance (Ali, 2020; Bolliger \& Martin, 2018). Many of those factors relate to the assumption that online teaching is time-consuming and demanding in preparation, requires higher efforts to build a relationship between educator and student, and the perceived success is often tied to the lecturer's media literacy and skills to engage with students online (Bolliger \& Martin, 2018; Zhang et al., 2020). Previous publications additionally illustrated that accepting online teaching is highly dependent on individual factors. A high teaching load and long experience in a traditional teaching environment typically result in a skeptical position towards online teaching (Bolliger $\&$ Martin, 2018). When it comes to demographic characteristics, younger female educators were more open to online teaching before the pandemic hit (Horvitz at al., 2015). Most of these assessments are likely to be present in the field of social science methods education as well.

Furthermore, previous studies have shown research methods education to thrive when it is possible for lecturer/student interaction, elaborate feedback procedures and exercises to work together (Michaelsen \& Sweet, 2008; Prandner \& Tabakovic, 2019). It has been monitored over decades that tutorials and applying gained knowledge are necessary for students to develop methods skills. It also became evident that - despite the fact that regularly expected methods skills can be generalized - there is no homogenous pedagogical style that has been established to teach them, resulting in a generally higher burden for those who teach courses that deal with such a content (Nind \& Lewthwaite, 2018; Prandner \& Tabakovic, 2019).

\section{The Dataset and the Methods Used}

The survey that is the background of this case study is part of Digitize!, funded by the Austrian Federal Ministry for Education, Science and Research. The survey is meant to constantly monitor the digitalization of social science research method education in Austria beginning in 2020. While the project was meant to start in September 2020, the COVID-19 pandemic and its influence on the universities forced the researchers to accelerate their 
timetable and begin in March 2020. Furthermore, the project no longer has to observe a field that may slowly adapt to new teaching methods but one that has been radically transformed in recent months.

The population for the study was defined as university level educators who teach social science research courses and method classes in the four core disciplines of the social sciences at the public universities of Austria: Sociology, political science, communication studies and educational sciences. The corresponding individuals were identified via the lecture registers for bachelor and master programs, published by the public universities of Austria. Regarding the first wave, 182 individuals teaching social science research courses and method classes could be identified. Regarding the second wave, 126 additional educators became part of the population (total $\mathrm{n}=308$ for both waves). They were contacted via an individualized e-mail addressed to their official university e-mail accounts. Those were sent in March 2020 for the first wave and in September 2020 for the second one, with an additional reminder following after two weeks. Participants were given information about their rights in accordance with the General Data Protection Regulation. The questionnaire used closed questions to gather information about relevant demographic information (e.g. discipline, gender, years of experience, position) before identifying the respondents' pedagogical strategies, and feelings and experiences with online teaching and assessments.

The survey was piloted initially in mid-March, mostly consisting of established scales from the educational sciences. The online survey itself was conducted via the German provider Socscisurvey. Items and scales used for this paper and their distribution can be found in Table 1. The independent variables used are tied directly to the influences discussed in section 2 . The response rate for the first wave was a surprisingly high $58 \%(\mathrm{n}=105)$. The second wave had a response rate of $21 \%(n=64)$, more in line with other online surveys.

Sixty-three percent of social science methods instructors surveyed are women, with an average age of 43 years. Seventeen percent are junior scientists (e.g. predocs, assistants, project assistants). A quarter are tenured. The teaching average is about 5 units of 45 minutes per week, while the participants have an average of 11 years teaching experience in methodology or empirical methods. Prior to the COVID-19 pandemic, there was hardly any experience with distance teaching. Eighty-five percent of the respondents teach courses where students are continuously assessed, resulting in a high level of interaction between educators and students and among students. More than half of the respondents have tried many new didactic methods (e.g. use new online-teaching tools and communication platforms to engage with students), which can typically be seen as a proxy for media competency. However, distance teaching is perceived by a large proportion of respondents $(81 \%)$ as more time-consuming in terms of preparation and follow-up. More than half of the respondents also find interaction with students in a distance mode more challenging. 
Table 1. Dependent and Independent Variables

\begin{tabular}{|c|c|c|c|c|}
\hline \multicolumn{2}{|c|}{ Dimension } & \multirow{2}{*}{$\begin{array}{l}\text { Variable } \\
\text { Distance teaching is only a temporary } \\
\text { solution }(n=142)\end{array}$} & \multirow{3}{*}{$\begin{array}{l}\text { Scale } \\
\text { 1- strongly agree } \\
\text { to } 5 \text { - strongly } \\
\text { disagree }\end{array}$} & \multirow{3}{*}{$\begin{array}{c}\begin{array}{c}\text { Mean } \\
\text { (st.Dev.) }\end{array} \\
\text { /Median/ } \\
\text { percent }^{1} \\
3.0\end{array}$} \\
\hline \multirow{2}{*}{ 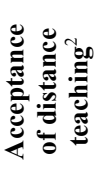 } & $\begin{array}{l}\text { Temporary } \\
\text { solution }\end{array}$ & & & \\
\hline & $\begin{array}{l}\text { Permanent } \\
\text { implement- } \\
\text { ation }\end{array}$ & $\begin{array}{l}\text { I will continue to implement aspects of } \\
\text { online teaching after the pandemic }(n= \\
139)\end{array}$ & & \\
\hline \multirow{3}{*}{ 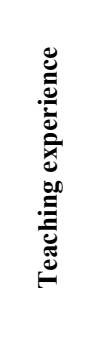 } & $\begin{array}{l}\text { Teaching } \\
\text { units per } \\
\text { week }\end{array}$ & $\begin{array}{l}\text { How many teaching units did you teach } \\
\text { per week this semester? }(\mathrm{n}=155)\end{array}$ & $\begin{array}{l}\text { metric } \\
\text { (nr. of units) }\end{array}$ & $\begin{array}{r}4.86 \\
(3.53)\end{array}$ \\
\hline & \multirow{2}{*}{$\begin{array}{l}\text { Extent of } \\
\text { teaching } \\
\text { experience }\end{array}$} & $\begin{array}{l}\text { How many years have you been teaching } \\
\text { empirical research methods and/or } \\
\text { methodology? }(n=149)\end{array}$ & \multirow{2}{*}{$\begin{array}{l}\text { metric } \\
\text { (no. of years) }\end{array}$} & $\begin{array}{l}10.91 \\
(8.36)\end{array}$ \\
\hline & & $\begin{array}{l}\text { How many years have you been teaching } \\
\text { empirical research methods and/or } \\
\text { methodology via distance teaching? }(n= \\
\text { 141) }\end{array}$ & & $\begin{array}{r}0.93 \\
(2.20)\end{array}$ \\
\hline 范 & $\begin{array}{l}\text { Continuous } \\
\text { assessment in } \\
\text { class }\end{array}$ & $\begin{array}{l}\text { Did you teach courses with seminar, } \\
\text { project, or practical course character? }(n= \\
169)\end{array}$ & $\begin{array}{l}\text { multiple answer } \\
\text { recoded into } \\
1=\text { yes; } 0=\text { no }\end{array}$ & 85.2 \\
\hline \multirow{3}{*}{ 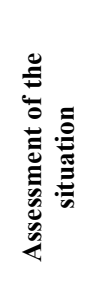 } & $\begin{array}{l}\text { Openness to } \\
\text { new didactics }\end{array}$ & $\begin{array}{l}\text { I try out many new didactic methods. }(\mathrm{n}= \\
146)\end{array}$ & \multirow{3}{*}{$\begin{array}{l}\text { ordinal scales; } \\
\text { recoded into } \\
1=\text { (strongly) } \\
\text { agree; } \\
0=\text { neither agree } \\
\text { nor disagree, } \\
\text { (strongly) } \\
\text { disagree }\end{array}$} & 54.1 \\
\hline & $\begin{array}{l}\text { Perception of } \\
\text { additional } \\
\text { preparation }\end{array}$ & $\begin{array}{l}\text { I currently need more time than usual to } \\
\text { prepare and follow up my lessons. }(n= \\
142)\end{array}$ & & 81.0 \\
\hline & $\begin{array}{c}\text { Interaction } \\
\text { with students }\end{array}$ & $\begin{array}{l}\text { I find interaction with students via distance } \\
\text { learning is harder to organize }(n=143)\end{array}$ & & 53.8 \\
\hline \multirow{5}{*}{ ie } & Female & $\begin{array}{l}\text { With which gender do you identify? }(\mathrm{n}= \\
144)\end{array}$ & $\begin{array}{l}1=\text { female } \\
0=\text { male }\end{array}$ & 62.5 \\
\hline & Age & How old are you? $(n=142)$ & $\begin{array}{l}\text { metric } \\
\text { (no. of years) }\end{array}$ & $\begin{array}{r}43.03 \\
(10.36)\end{array}$ \\
\hline & $\begin{array}{l}\text { Junior } \\
\text { scientists }\end{array}$ & $\begin{array}{l}\text { How would you describe your current } \\
\text { professional position? }(\mathrm{n}=144)\end{array}$ & $\begin{array}{l}1=\text { junior } \\
\text { scientists } \\
0=\text { others }\end{array}$ & 17.4 \\
\hline & Tenure & $\begin{array}{l}\text { My current employment contract is } \ldots \text { ( } n= \\
169 \text { ) }\end{array}$ & $\begin{array}{l}1=\text { tenured } \\
0=\text { temporary }\end{array}$ & 25.4 \\
\hline & Survey wave & $(n=169)$ & $\begin{array}{l}1=\text { fall } 2020 \\
0=\text { spring } 2020\end{array}$ & 37.9 \\
\hline
\end{tabular}

Source: Digitize!-Panel-Study on Methods Education (2020).

\footnotetext{
${ }^{1}$ Percentage always states the amount of answers coded with 1.

${ }^{2}$ Factor solution for linear regression: 1 factorial solution - extracted variance: 82.37 / eigenvalue: 1.65 ; Cronbach's alpha: 0.78
} 


\section{Who Embraces the Digitalization of Research Education?}

The fact that nearly all lecturers were forced to adapt to the new circumstances during the COVID-19 pandemic resulted in a situation where the majority had a (strong) opinion on whether distance teaching is just a stopgap or if it should be kept after the pandemic. In this regard, it can be reported that about $15 \%$ of the respondents agreed strongly that they consider distance teaching to be an emergency solution, while another $28 \%$ somewhat agreed. Nine percent do not consider distance teaching as a temporary solution at all. Fifteen percent of respondents are certain that they will continue to offer some of their teaching over distance, even after the pandemic ends. Another quarter are likely to do so as well. Sixteen percent cannot imagine a future implementation of distance teaching at all (see Figure 1 for details).

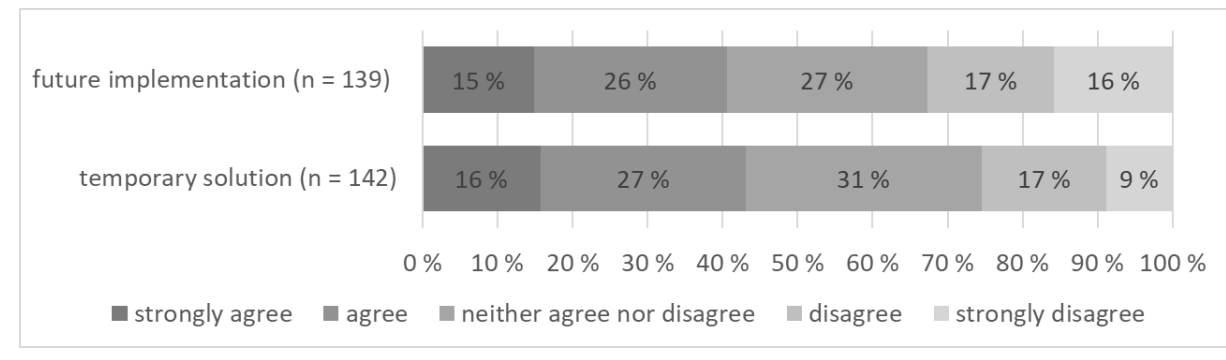

Figure 1. Attitudes towards distance learning. Source: Digitize! Panel Study on Methods Education (2020).

A more detailed look emerges when considering the results of a linear regression on the acceptance of distance teaching by social science methods instructors. Two models were calculated to do this. The first model deals with the extent of teaching and the teaching experience and the mode of the courses and evaluation of the situation were included. In a second model, sociodemographic data were also included to check for their influence. A variable identifying the timing of the survey was included in both models.

Results show that neither the extent of traditional nor that of online teaching experience have a significant impact on the acceptance of distance teaching. This is also true for the question whether an instructor taught courses that require continuous assessment of students or not. The number of teaching hours has only a tendency to positively influence the attitude towards distance teaching when sociodemographic variables are not considered. However, educators who are open to new didactic approaches are also more positive about distance teaching. Following the assumption that trying new didactic methods in online teaching requires the media literacy and skills to engage with students online, parallels to the literature can be seen here. As expected, the perception of a longer preparation time for distance teaching compared to face-to-face teaching and the negative experience regarding the difficulty of interacting with students have a negative impact on the acceptance of distance teaching. 
Age, gender and whether someone is in a temporary or permanent employment relationship do not directly affect the acceptance of distance teaching. Considering these variables, however, makes a tendency toward lower acceptance for distance teaching among in junior researchers $(p<0.10)$ evident. The survey timing also plays a significant role in the acceptance of distance teaching. In both models, distance learning is viewed more favorably during the second survey in the fall of 2020 when compared to spring 2020. This seems logical, as lecturers had time to come to terms with distance teaching, after a rather abrupt change in the spring. Educators and students had already adjusted to the new situation and gained experience. It is also likely that there had been a significant investment regarding the change to distance teaching, therefore, the desire to retain parts of it even after the pandemic ended may have increased.

Table 2. Acceptance of distance teaching

\begin{tabular}{|c|c|c|c|}
\hline \multicolumn{4}{|c|}{ Linear regression for: Acceptance of distance teaching (regression constant) } \\
\hline \multirow{4}{*}{ Teaching experience } & Independent Variables & Model 1 & Model 2 \\
\hline & miepenuent vanaies & Std. Beta & Std. Beta \\
\hline & Teaching hours per week & $0.157 \sim$ & 0.158 \\
\hline & Open-mindedness to new didactic concepts & $0.209^{*}$ & $0.198 *$ \\
\hline \multirow{4}{*}{$\begin{array}{l}\text { Assessment of the } \\
\text { situation }\end{array}$} & Perception of additional preparation & $-0.166^{*}$ & $-0.190 *$ \\
\hline & Interaction with students is harder & $-0.198 *$ & $-0.211^{*}$ \\
\hline & Junior scientists & - & $-0.161 \sim$ \\
\hline & Survey wave & $0.197 *$ & $0.178^{*}$ \\
\hline $\mathbf{n}=$ & & 124 & 122 \\
\hline $\mathbf{R}^{2}$ & & 0.24 & 0.27 \\
\hline $\mathbf{R}^{2}$ change & & & +0.03 \\
\hline
\end{tabular}

\section{Discussion}

The COVID-19 pandemic made distance teaching a reality at most universities worldwide. The results of the Austrian case study on social science method educators show that more than $40 \%$ of the sample are going to keep some aspects of distance teaching in their (methods) lectures after this unusual experience. However, an equally sizeable part remains sceptic. Furthermore, in the level playing field of the pandemic, previous assumptions about gender or age bias were proven insignificant. The same was true regarding the type of course - and, thus, content - taught. It can be seen that experiences during the pandemic are of relevance instead: Those who feel an additional burden - be it in preparation or student interaction - are more likely to reject distance teaching, while those who have the competencies or interest in tinkering with their teaching are more likely to embrace a future with distance teaching. This is an important assessment: Trying out new techniques and 
teaching methods will improve online teaching and may lessen the stigma it experiences in highly interaction-based disciplines - such as the social science methods education researched.

\section{References}

Ali, W. (2020). Online and remote learning in higher education institutes: a necessity in light of COVID-19 pandemic. Higher Education Studies, 10(3), 16-25.

Bolliger, D. U., \& Martin, F. (2018). Instructor and student perceptions of online student engagement strategies. Distance Education, 39(4), 568-583.

Earley, M. A. (2014). A synthesis of the literature on research methods education. Teaching in Higher Education, 19(3), 242-253. https://doi.org/10.1080/13562517.2013.860105

Horvitz, B. S., Beach, A. L., Anderson, M. L., \& Xia, J. (2015). Examination of faculty selfefficacy related to online teaching. Innovative Higher Education, 40(4), 305-316.

Ivancheva, M. P., Swartz, R., Morris, N. P., Walji, S., Swinnerton, B. J., Coop, T., \& Czerniewicz, L. (2020). Conflicting logics of online higher education. British Journal of Sociology of Education, 41(5), 608-625.

Marshall, S. J. (2018). Shaping the University of the Future: Using Technology to Catalyse Change in University Learning and Teaching. Singapore: Springer.

Michaelsen, L. K., \& Sweet, M. (2008). The essential elements of team-based learning. New Directions for Teaching and Learning, 2008(116), 7-27. https://doi.org/10.1002/tl.330

Nardi, P. M. (2018). Doing Survey Research: A Guide to Quantitative Methods (4th ed.). Milton: Taylor and Francis.

Nind, M., \& Lewthwaite, S. (2018). Methods that teach: developing pedagogic research methods, developing pedagogy. International Journal of Research \& Method in Education, 41(4), 398-410. https://doi.org/10.1080/1743727X.2018.1427057

Prandner, D., \& Tabakovic, A. (2019). Measuring which support systems really work to improve students learning in your class. HEAd'19. Valencia: Universitat Politècnica València. https://doi.org/10.4995/HEAd19.2019.9133

Tømte, C. E., Fossland, T., Aamodt, P. O., \& Degn, L. (2019). Digitalisation in higher education: Mapping institutional approaches for teaching and learning. Quality in Higher Education, 25(1), 98-114. https://doi.org/10.1080/13538322.2019.1603611

Watermeyer, R., Crick, T., Knight, C., \& Goodall, J. (2020). Covid-19 and digital disruption in UK universities: Afflictions and affordances of emergency online migration. Higher Education, 81, 623-641. https://doi.org/10.1007/s10734-020-00561-y

Zhang, W., Wang, Y., Yang, L., \& Wang, C. (2020). Suspending classes without stopping learning: China's education emergency management policy in the COVID-19 outbreak. Journal of Risk and Financial Management, 13(3), 55. https://doi.org/10.3390/jrfm13030055 